$\underset{\text { clinical }}{\text { nephron }}$

Practice
Nephron 2017;137:287-293

DOI: $10.1159 / 000478538$
Received: April 18, 2017

Accepted after revision: June 9, 2017 Published online: June 30, 2017

\title{
Lymphocyte Function in Human Acute Kidney Injury
}

\author{
Sophie Weller Matt Varrier Marlies Ostermann \\ Department of Critical Care, King's College London School of Medical Education, Guy's and St Thomas' NHS \\ Foundation Trust, London, UK
}

\section{Keywords}

Acute kidney injury · Lymphocytes · Inflammation · T cells

\begin{abstract}
Acute kidney injury (AKI) has been recognised as an inflammatory condition with serious short- and long-term complications. Animal studies primarily using models of ischaemia reperfusion injury or caecal ligation and perforation have clearly demonstrated that inflammatory cells contribute to the initiation, propagation and recovery phase of AKI and that lymphocytes have a key role in these processes. Less is known about their involvement in common types of human AKI. This paper summarises the key findings of experimental AKI studies and limited human data with particular focus on the role of T-lymphocytes.

ㄷ) 2017 S. Karger AG, Basel
\end{abstract}

\section{Introduction}

Acute kidney injury ( $\mathrm{AKI}$ ) is a serious complication of critical illness impacting short-and long-term prognosis. Although it is a heterogeneous syndrome with multiple potential aetiologies, there is increasing evidence that inflammatory processes contribute to the initiation, propagation and recovery phase of renal injury. Experimental studies in animals and preliminary human data have suggested that lymphocytes play a key role.

\section{KARGER}

๑) 2017 S. Karger AG, Basel

E-Mail karger@karger.com

www.karger.com/nef
The aims of this paper are to review the biological roles of different sub-types of lymphocytes (Table 1), to summarise the key findings of experimental AKI studies and to describe the data in human AKI.

\section{Role of Lymphocytes in Experimental AKI}

The basic premise that AKI is caused by ischaemia of the vulnerable renal tubular cells has led to the predominant use of ischaemia-reperfusion injury (IRI) models involving clamping and release of renal arteries in experimental models of AKI. This has generated studies involving rodents constitutively deficient in specific immune cells that have demonstrated the important role of lymphocytes in different types and phases of AKI [1-11] (Tables 2, 3). Classically associated with immune responses elicited by specific antigen recognition, these key components of the adaptive immune system have been proven to have a prominent role in experimental AKI both in the absence of antigen and before such time as antigenic response could be generated.

Contribution from the AKI \& CRRT 2017 Symposium at the 22nd International Conference on Advances in Critical Care Nephrology, Manchester Grand Hyatt, San Diego, Calif., USA, March 7-10, 2017. This symposium was supported in part by the NIDDK funded University of Alabama at Birmingham-University of California San Diego O'Brien Center for Acute Kidney Injury Research (P30 DK079337).

Dr. Marlies Ostermann

Department of Critical Care, King's College London School of Medical Education Guy's and St Thomas' NHS Foundation Trust

London SE1 7EH (UK)

E-Mail Marlies.Ostermann@gstt.nhs.uk 
Table 1. Potential roles of different lymphocyte subtypes in AKI

\begin{tabular}{|c|c|c|}
\hline Lymphocyte type & Typical mediators & Physiological functions in AKI \\
\hline Naïve CD4+ T-cell & & $\begin{array}{l}\text { - Differentiation into effector cells following activation by specific antigens and } \\
\text { co-stimulatory signals }\end{array}$ \\
\hline CD8+ cytotoxic T-cell & $\begin{array}{l}\text { Perforin } \\
\text { Granzymes } \\
\text { TNF- } \alpha \\
\text { IFN- } \gamma\end{array}$ & $\begin{array}{l}\text { - Destruction of cells } \\
\text { - Increased IFN- } \gamma \text { production } \\
\text { - Primary response often requires help from CD } 4+\text { T-cells }\end{array}$ \\
\hline Th1 cell & $\begin{array}{l}\text { IL-2 } \\
\text { IFN- } \gamma \\
\text { TNF- } \beta\end{array}$ & $\begin{array}{l}\text { - Promotion of inflammation } \\
\text { - Activation of CD8+ cells, macrophages and B-cells }\end{array}$ \\
\hline Th2 cell & $\begin{array}{l}\text { IL-3 } \\
\text { IL-4 } \\
\text { IL-5 } \\
\text { IL-10 } \\
\text { IL-13 }\end{array}$ & $\begin{array}{l}\text { - Activation and recruitment of B-cells, mast cells, basophils, eosinophils and } \\
\text { macrophages } \\
\text { - Inhibition of inflammatory response }\end{array}$ \\
\hline T-regulatory cell (T-reg) & $\begin{array}{l}\text { TGF- } \beta \\
\text { IL-35 } \\
\text { IL-10 } \\
\text { Granzymes }\end{array}$ & $\begin{array}{l}\text { - Inhibition of dendritic cells } \\
\text { - Cytotoxic to target cells } \\
\text { - Inhibition of inflammatory cells } \\
\text { - Depletion of available IL-2 }\end{array}$ \\
\hline CD4- CD8- DN T-cell & IL-10 & - Protective role in ischaemic injury \\
\hline NK T-cell & $\begin{array}{l}\text { IFN- } \gamma \\
\text { IL-2 } \\
\text { IL-4 } \\
\text { IL-10 } \\
\text { IL-18 }\end{array}$ & $\begin{array}{l}\text { - Recognition of lipids and glycolipids presented by the CD1 molecule rather } \\
\text { than peptide MHCs } \\
\text { - Induction of renal inflammation and injury or protection from it depending } \\
\text { on the context of activation } \\
\text { - Contribution to neutrophil activation }\end{array}$ \\
\hline
\end{tabular}

Th1, T-helper 1; Th2, T-helper 2; Th-17, T-helper 17; NK, natural killer; AKI, acute kidney injury; CD, cluster of differentiation; DN, double negative; IFN, interferon; IL, interleukin; MHC, major histocompatibility complex; TGF, transforming growth factor; TNF, tumour necrosis factor.

Cluster of differentiation (CD) 4+ T-cells and subsequent cell lines, in particular T helper 1 (Th1) and T helper 2 cells (Th2 cells) (Fig. 1) have been shown to contribute to the pathophysiology of AKI. Th1 cells produce proinflammatory interferon-gamma (IFN- $\gamma$ ) and interleukin (IL)-2, whereas Th2 cells secrete predominantly IL- 4 and IL-10 (both anti-inflammatory) and other cytokines. Both cell types appear to be involved in the early injury phase of IRI $[5,12]$ (Table 2). Mice deficient in CD4 and CD8 were functionally and structurally protected in IRI
[5]. Reconstitution with transfer of CD4+ restored the injured phenotype but not with $\mathrm{CD} 8+$ cells alone. Other experiments confirmed that CD4+ and CD8+ T cells isolated from post-ischaemic kidneys produced more IFN- $\gamma$ and tumour necrosis factor- $\alpha$ compared to normal or sham-operated kidneys [8], again confirming a key role of $\mathrm{T}$ cells in AKI.

There is also evidence that activated CD4+ and CD8+ $\mathrm{T}$ cells are present in the recovery phase at 6 weeks postIRI and may be implicated in ongoing damage [10]. 
Table 2. Role of lymphocytes in acute kidney injury in selected experimental murine models

\begin{tabular}{|c|c|c|c|}
\hline Publication & Experimental murine model & Key findings & Phase of AKI \\
\hline Burne et al. [5] & Aseptic bilateral IRI & $\begin{array}{l}\text { - CD4+ T-cell deficiency was renoprotective } \\
\text { - CD8+ T-cell deficiency was not renoprotective } \\
\text { - The effect of CD4+ T-cells was dependent on CD28 and IFN- } \gamma\end{array}$ & $\begin{array}{l}\text { Injury: } \\
24 \text { and } 48 \mathrm{~h}\end{array}$ \\
\hline Ascon et al. [6] & Aseptic bilateral IRI & $\begin{array}{l}\text { - Role of CD3+ T-cells and NK T-cells in early IRI } \\
\text { - Increased production of TNF- } \alpha \text { and IFN- } \gamma \text { at } 24 \mathrm{~h} \\
\text { - Transfer of infiltrating lymphocytes to T-cell deficient mice was renoprotective } \\
\text { at } 24,48 \text {, and } 72 \mathrm{~h}\end{array}$ & $\begin{array}{l}\text { Injury: } \\
24,48 \text {, and } 72 \mathrm{~h}\end{array}$ \\
\hline Wang et al. [7] & $\begin{array}{l}\text { Aseptic unilateral IRI and } \\
\text { contralateral nephrectomy }\end{array}$ & - Reduced CD4+ T-cell infiltration following IRI in IL-16 deficient mice & $\begin{array}{l}\text { Injury: } \\
48 \mathrm{~h}\end{array}$ \\
\hline Zhang et al. [20] & $\begin{array}{l}\text { Aseptic unilateral IRI and } \\
\text { contralateral nephrectomy }\end{array}$ & $\begin{array}{l}\text { - NK T-cells induced apoptotic death of tubular epithelial cells and contributed to } \\
\text { effects of IRI }\end{array}$ & $\begin{array}{l}\text { Injury: } \\
48 \mathrm{~h}\end{array}$ \\
\hline Ascon et al. [8] & $\begin{array}{l}\text { Healthy mice and aseptic } \\
\text { bilateral IRI }\end{array}$ & $\begin{array}{l}\text { - Identification of resident CD4+, CD8+ and CD4-CD8- DN T-cells in healthy } \\
\text { mouse kidney } \\
\text { - Increased production of IFN- } \gamma \text { and TFN- } \alpha \text { by CD4+ and CD } 8+\text { T-cells after IRI } \\
\text { - Suggestion that cells harbored in the kidney are implicated in the immune } \\
\text { response of IRI }\end{array}$ & $\begin{array}{l}\text { Injury: } \\
0,3 \text {, and } 24 \mathrm{~h}\end{array}$ \\
\hline Lee et al. [13] & $\begin{array}{l}\text { Septic caecal ligation and } \\
\text { puncture versus IRI }\end{array}$ & $\begin{array}{l}\text { - Septic injury was associated with increased IL-10, massive immune cell } \\
\text { apoptosis and increased T-regs } \\
\text { - T-reg depletion was renoprotective before caecal ligation and puncture but } \\
\text { aggravated injury in IRI } \\
\text { - Blocking IL-10 was renoprotective in septic mice but had no effect in IRI }\end{array}$ & $\begin{array}{l}\text { Injury: } \\
24 \mathrm{~h}\end{array}$ \\
\hline Liu et al. [21] & $\begin{array}{l}\text { Acute cisplatin } \\
\text { nephrotoxicity }\end{array}$ & $\begin{array}{l}\text { - CD4+ and CD8+ T-cells were direct mediators of experimental cisplatin } \\
\text { nephrotoxicity }\end{array}$ & $\begin{array}{l}\text { Injury: } \\
24 \mathrm{~h}\end{array}$ \\
\hline $\begin{array}{l}\text { Burne-Taney } \\
\text { et al. [9] }\end{array}$ & Aseptic bilateral IRI & $\begin{array}{l}\text { - B-cell deficient mice were protected from effects of IRI at } 24,48 \text { and } 72 \mathrm{~h} \text { despite } \\
\text { similar levels of CD4+ cell infiltration }\end{array}$ & $\begin{array}{l}\text { Injury: } \\
24-72 \mathrm{~h}\end{array}$ \\
\hline Ascon et al. [10] & $\begin{array}{l}\text { Aseptic bilateral and } \\
\text { unilateral IRI }\end{array}$ & $\begin{array}{l}\text { - Increase of CD8+ T-cells } 2 \text { weeks after IRI } \\
\text { - Infiltration of CD4+ and CD8+ T-cells } 6 \text { weeks after IRI } \\
\text { - Decrease of CD4+ NK T-cells and CD19+ B cells } 6 \text { and } 11 \text { weeks post IRI } \\
\text { - Depletion of CD4+ and CD8+ T-cells before IRI resulted in less medullary damage } \\
\text { and cytokine expression }\end{array}$ & $\begin{array}{l}\text { Long term: } 2,6 \text {, } \\
\text { and } 11 \text { weeks } \\
\text { post-injury }\end{array}$ \\
\hline
\end{tabular}

AKI, acute kidney injury; ATN, acute tubular necrosis; CD, cluster of differentiation; DN, double negative; IFN, interferon; IRI, ischaemia reperfusion injury; NK, natural killer; TNF, tumour necrosis factor.

T-regulatory cells (T-regs) are a subset of CD4+ T cells. Activated T-regs can directly suppress the activation and proliferation of $\mathrm{T}$ cells and even induce apoptosis via secretion of anti-inflammatory cytokines (IL10, IL-35 and transforming growth factor-beta) and depletion of available IL-2. There is compelling data that they play an important role in experimental AKI. Aseptic IRI models showed that T-regs attenuated injury in the initial phase and enhanced repair (Table 2). Depletion of T-regs using an anti-CD25 monoclonal antibody exacerbated renal tubular damage, reduced tubular proliferation and increased pro-inflammatory cytokine produc- 
Table 3. Role of lymphocyte subsets in different AKI phases based on experimental models

\begin{tabular}{|c|c|c|c|}
\hline $\begin{array}{l}\text { Lymphocyte } \\
\text { subset }\end{array}$ & Early injury & Late injury/recovery phase & Key interactions \\
\hline $\begin{array}{l}\text { Cytotoxic } \\
\text { T-cells }\end{array}$ & $\begin{array}{l}\text { - CD } 8+\text { cells up-regulate IFN- } \gamma 24 \mathrm{~h} \\
\text { post IRI [6] } \\
\text { - The absence does not protect against } \\
\text { AKI [5] }\end{array}$ & $\begin{array}{l}\text { - Infiltration may persist for several } \\
\text { weeks post AKI and may be } \\
\text { implicated in chronic damage [10] }\end{array}$ & $\begin{array}{l}\text { - Likely to act synergistically with } \\
\text { multiple cell lines through cytokine } \\
\text { production and co-stimulation }\end{array}$ \\
\hline T-regs & $\begin{array}{l}\text { - Attenuation of renal injury through } \\
\text { IL-10 mediated suppression of the } \\
\text { innate immune system [3] }\end{array}$ & $\begin{array}{l}\text { - Likely to be a key modulator. } \\
\text { - Associated with enhanced tubular } \\
\text { recovery and repair }\end{array}$ & $\begin{array}{l}\text { - Inhibit pro-inflammatory cytokines } \\
\text { from T-helper cells [2] } \\
\text { - Likely to help switching of macrophages } \\
\text { to an anti-inflammatory M2 phenotype } \\
\text { in recovery phase }\end{array}$ \\
\hline B-cells & $\begin{array}{l}\text { - Attenuation of IRI in B-cell-deficient } \\
\text { mice [9] }\end{array}$ & $\begin{array}{l}\text { - Infiltrating cells mature to plasma } \\
\text { cells and have a deleterious effect on } \\
\text { tubular recovery [11] }\end{array}$ & $\begin{array}{l}\text { - Likely to act synergistically with } \\
\text { multiple cell lines through cytokine } \\
\text { production and co-stimulation }\end{array}$ \\
\hline NK T-cells & $\begin{array}{l}\text { - Very early infiltration and IFN- } \gamma \\
\text { production appear to have deleterious } \\
\text { effects }[6,18] \text {. } \\
\text { - Type II NK T-cell subtype may be } \\
\text { protective [28] }\end{array}$ & - No data available & $\begin{array}{l}\text { - May have a positive feedback loop of } \\
\text { activation and IFN- } \gamma \text { production with } \\
\text { neutrophils }\end{array}$ \\
\hline
\end{tabular}

AKI, acute kidney injury; CD, cluster of differentiation; DN, double negative; IFN, interferon; IL, interleukin; IRI, ischaemia reperfusion injury; NK, natural killer.

tion after IRI [2]. Adoptive transfer of T-regs improved repair and reduced the generation of pro-inflammatory cytokines.

Interestingly, there is also evidence of a possible opposing role in relation to the role of T-regs in IRI and sepsis. Their depletion pre-injury was found to aggravate renal injury in a murine IRI model, whereas their depletion in a septic model using caecal ligation and puncture was reno-protective [13].

It has been suggested that $\mathrm{CD} 4 / \mathrm{CD} 8$ double negative (DN) T cells are also involved in the pathogenesis of IRI. In a murine bilateral IRI model, DN T cells expanded early to become dominant subsets and maintained dominance until $24 \mathrm{~h}$ after IRI [4]. Global gene expression analysis of DN T cells before and after IRI revealed 16-fold upregulation of the gene encoding the anti-inflammatory cytokine IL-10 suggesting a protective role. This beneficial effect was elegantly demonstrated by adoptive transfer of DN T-cells into wild-type mice 24 $\mathrm{h}$ before IRI. The animals were significantly protected from AKI compared to control mice transfused unseparated $\mathrm{T}$ cells. The administration of a monoclonal antibody that blocked IL-10 receptors inhibited the protective effect.

Although B cells are classically associated with antibody production, they have an important role in the cellular response via T-cell activation and cytokine generation too [14]. They have been implicated in the injury phase of septic AKI and also been shown to impair recovery after ischaemic AKI $[9,11]$. Following IRI, B cells comprised important constituents of the immune cell infiltrate, and B-cell deficiency conferred protection from IRI [9]. B-cell-deficient mice had attenuated renal injury, increased tubular proliferation and higher IL-10 expression $[9,11]$. Adoptive transfer of serum into B-cell-deficient mice partially restored the ischemic phenotype [9] and transfer of B cells reduced tubular proliferation and increased tubular atrophy [11].

Conversely, a protective antibody-mediated role for $\mathrm{B}$-cell involvement in AKI has also been identified via 
Fig. 1. Differentiation of $\mathrm{T}$ cells. Th, T-helper; DN, double negative; T-reg, $\mathrm{T}$ regulatory cell.

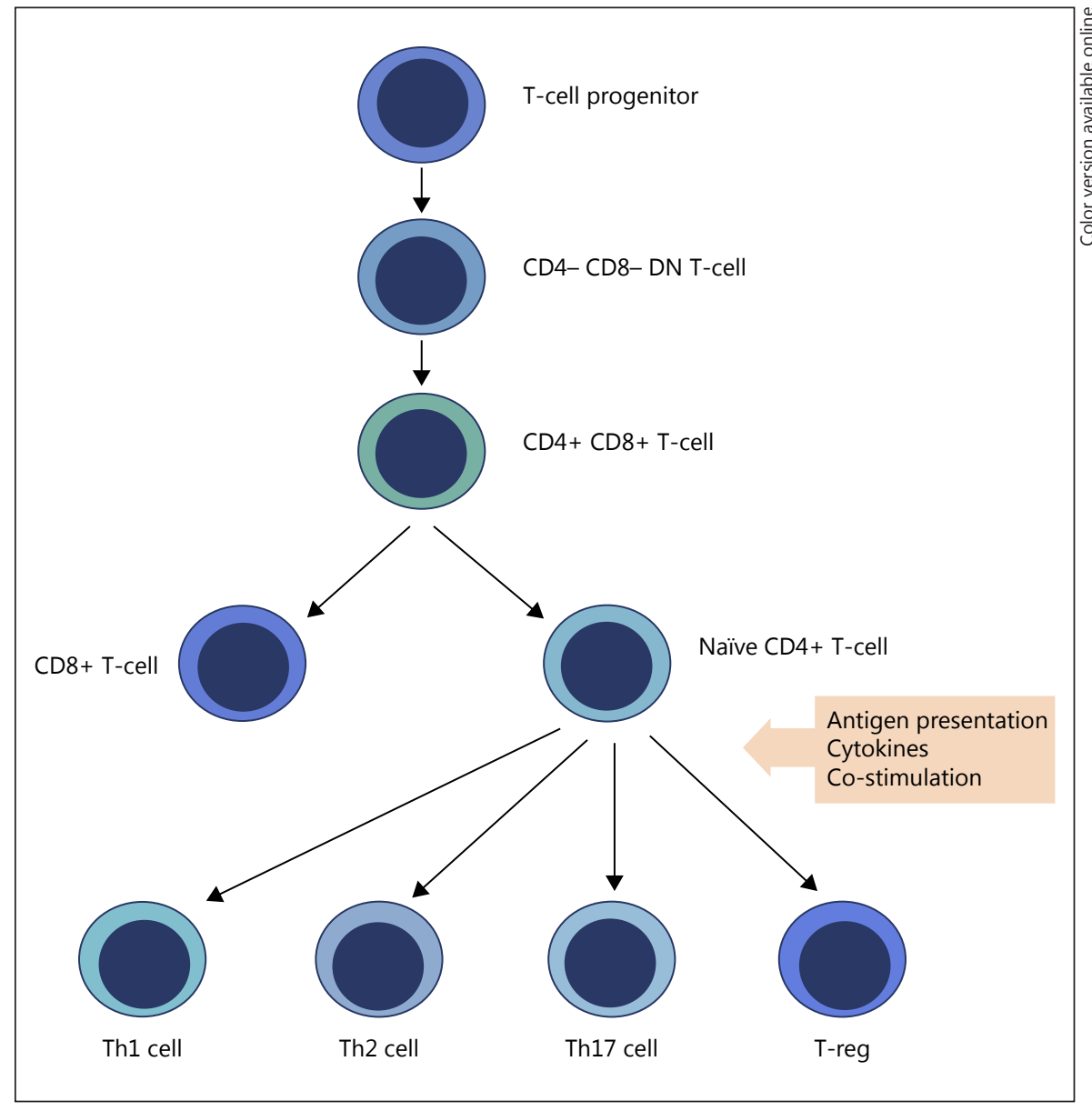

natural immunoglobulin (Ig) $\mathrm{M}$ - anti-leukocyte antibodies (ALA), which are characteristically increased early during inflammatory and infective conditions [15]. Natural IgM-ALA inhibits pro-inflammatory $\mathrm{T}$ cells from proliferating and producing IFN- $\gamma$ and IL-17 in response to noxious stimuli. In IgM knock-out mice, natural IgM enriched in ALA protected against IRI [15].

In the last decade, B-regulatory cells (B-regs) have been appreciated as important types of B cells with distinct and contrasting suppressive and tolerogenic properties [16]. They are able to suppress Th1 and Th17 cell differentiation [16]. Their exact role in human AKI remains unclear.

Natural killer (NK) T cells are a heterogeneous group of $\mathrm{T}$ cells that share properties of both $\mathrm{T}$ cells and NK cells. Many of these cells recognize lipids and glycolipids from organisms presented by the non-polymorphic CD1d molecule, an antigen-presenting molecule rather than peptide-major histocompatibility complexes. The clinical potential of NK T cells lies in the rapid release of cytokines (such as IL-2, IFN- $\gamma$, tumour necrosis factor- $\alpha$, and IL-4) and the ability to induce renal inflammation and injury or protect from it depending on the context of their activation [17]. Post IRI, infiltrating NK T-cells have been shown to stimulate IFN- $\gamma$ production and neutrophil infiltration [18]. Importantly, neutrophils may cause further activation of NK T-cells via IL-17, which ultimately creates a deleterious positive feedback loop and significant IFN- $\gamma$ production in ischaemic kidneys [19].

\section{Role of Lymphocytes in Specific Forms of AKI}

A major pitfall of experimental AKI is the inherent difference between the rodent and human immune system and kidneys themselves. In addition, most experimental models entail a single insult (often IRI) with a clearly defined time of onset using animals without any comorbid 
conditions. Therefore, it remains uncertain whether these findings can be applied to humans.

However, there is evidence that lymphocytes play a role in specific types of human AKI, including interstitial nephritis, lupus nephritis and transplant rejection. This is perhaps not surprising given that the uninjured kidney contains several types of $\mathrm{T}$ cells in the renal interstitium that can be activated locally.

\section{Interstitial Nephritis}

Acute interstitial nephritis is an important cause of AKI resulting from immune-mediated tubule-interstitial injury, typically triggered by drugs, infection or immune disorders. The hallmarks of drug-induced acute interstitial nephritis are interstitial oedema and interstitial inflammation with an inflammatory infiltrate typically composed of CD4+ T cells and mononuclear cells with a variable number of plasma cells and eosinophils. It is thought that the $\mathrm{T}$ cells orchestrating injury are activated locally in the kidney by APCs or migrate from neighbouring lymph nodes and cause a cascade of inflammatory interstitial reactions marked by cytokine release and subsequent tubule-interstitial injury [22].

Lymphocytic infiltrates are also regular features of infection-associated interstitial nephritis, for instance, HIV-associated nephropathy [23].

\section{Lupus Nephritis}

Lupus nephritis is an important cause of AKI and chronic kidney disease. Accumulating evidence suggests that anti-double-stranded DNA antibodies play a critical role in the pathogenesis. Typically, immune complex deposition is accompanied by complement activation, infiltration of immune cells, cytokine release and oxidative damage [24]. Both, B and T lymphocytes and their mediators participate at all levels in disease pathogenesis from initiation, perpetuation to tissue destruction and disease relapse [25].

\section{Transplant Rejection}

$\mathrm{T}$ cells are central to the process of AKI due to transplant rejection through allorecognition of foreign antigens and the induction of inflammatory processes leading to organ damage [26].

\section{Potential Role of Lymphocytes in AKI during Critical Illness}

The main causes of AKI in critically ill patients are sepsis, haemodynamic instability, volume depletion and nephrotoxicity, often in combination and succession. The exact role of lymphocytes in this setting is not known especially since renal biopsies are rarely performed.

Limited data from humans showed that patients with septic AKI had significantly higher serum levels of soluble CD25, a marker that is representative of T-regs compared to septic patients without AKI and non-septic patients [27]. The results of an active study exploring immune function in human AKI are awaited (ClinicalTrials.gov Identifier: NCT02470507).

\section{Conclusions}

There is overwhelming evidence that lymphocytes play a key role in experimental AKI. Their role is also well established in acute interstitial nephritis, lupus nephritis and transplant rejection. However, the contributions of different lymphocyte subsets in human AKI in the setting of critical illness are not fully established and results of ongoing studies are awaited.

\section{Disclosure Statement}

The authors have no conflicts of interest to declare.

\section{References}

1 Jang HR, Rabb H: Immune cells in experimental acute kidney injury. Nat Rev Nephrol 2015;11:88-101.

2 Gandolfo MT, Jang HR, Bagnasco SM, Ko GJ, Agreda P, Satpute SR, et al: Foxp3+ regulatory $\mathrm{T}$ cells participate in repair of ischemic acute kidney injury. Kidney Int 2009;76:717-729.

3 Kinsey GR, Sharma R, Huang L, Li L, Vergis $\mathrm{AL}, \mathrm{Ye} \mathrm{H}$, et al: Regulatory T cells suppress innate immunity in kidney ischemia-reperfusion injury. J Am Soc Nephrol 2009;20:1744-1753.
4 Martina MN, Noel S, Saxena A, Bandapalle S, Majithia R, Jie C, et al: Double-negative $\alpha \beta$ T cells are early responders to AKI and are found in human kidney. J Am Soc Nephrol 2016;27:1113-1123.

5 Burne MJ, Daniels F, El Ghandour A, Mauiyyedi S, Colvin RB, O'Donnell MP, et al: Identification of the CD4(+) $\mathrm{T}$ cell as a major pathogenic factor in ischemic acute renal failure. J Clin Invest 2001;108:12831290.
6 Ascon DB, Lopez-Briones S, Liu M, Ascon M, Savransky V, Colvin RB, et al: Phenotypic and functional characterization of kidney-infiltrating lymphocytes in renal ischemia reperfusion injury. J Immunol 2006;177:33803387.

7 Wang S, Diao H, Guan Q, Cruikshank WW, Delovitch TL, Jevnikar AM, et al: Decreased renal ischemia-reperfusion injury by IL-16 inactivation. Kidney Int 2008;73:318326. 
8 Ascon DB, Ascon M, Satpute S, Lopez-Briones S, Racusen L, Colvin RB, et al: Normal mouse kidneys contain activated and CD3+CD4- CD8- double-negative T lymphocytes with a distinct TCR repertoire. J Leukoc Biol 2008;84:1400-1409.

9 Burne-Taney MJ, Ascon DB, Daniels F, Racusen L, Baldwin W, Rabb H: B cell deficiency confers protection from renal ischemia reperfusion injury. J Immunol 2003;171:32103215.

10 Ascon M, Ascon DB, Liu M, Cheadle C, Sarkar C, Racusen L, et al: Renal ischemia-reperfusion leads to long term infiltration of activated and effector-memory T lymphocytes. Kidney Int 2009;75:526-535.

11 Jang HR, Gandolfo MT, Ko GJ, Satpute SR, Racusen L, Rabb H: B cells limit repair after ischemic acute kidney injury. J Am Soc Nephrol 2010;21:654-665.

12 Day YJ, Huang L, Ye H, Linden J, Okusa MD Renal ischemia-reperfusion injury and adenosine $2 \mathrm{~A}$ receptor-mediated tissue protection: role of macrophages. Am J Physiol Renal Physiol 2005;288:F722-F731.

13 Lee SY, Lee YS, Choi HM, Ko YS, Lee HY, Jo SK, et al: Distinct pathophysiologic mechanisms of septic acute kidney injury: role of immune suppression and renal tubular cell apoptosis in murine model of septic acute kidney injury. Crit Care Med 2012;40:29973006.
14 Hoffman W, Lakkis FG, Chalasani G: B cells, antibodies, and more. Clin J Am Soc Nephrol 2016;11:137-154.

15 Lobo PI, Bajwa A, Schlegel KH, Vengal J, Lee SJ, Huang L, et al: Natural IgM anti-leukocyte autoantibodies attenuate excess inflammation mediated by innate and adaptive immune mechanisms involving Th-17. J Immunol 2012;188:1675-1685.

16 Rosser EC, Mauri C: Regulatory B cells: origin, phenotype, and function. Immunity 2015;42:607-612.

17 Kinsey GR, Okusa MD: Expanding role of T cells in acute kidney injury. Curr Opin Nephrol Hypertens 2014;23:9-16.

18 Li L, Huang L, Sung SS, Lobo PI, Brown MG, Gregg RK, et al: NKT cell activation mediates neutrophil IFN-gamma production and renal ischemia-reperfusion injury. J Immunol 2007;178:5899-5911.

19 Li L, Huang L, Vergis AL, Ye H, Bajwa A, Narayan $\mathrm{V}$, et al: IL-17 produced by neutrophils regulates IFN-gamma-mediated neutrophil migration in mouse kidney ischemia-reperfusion injury. J Clin Invest 2010;120:331-342.

20 Zhang ZX, Wang S, Huang X, Min WP, Sun H, Liu W, Garcia B, Jevnikar AM: NK cells induce apoptosis in tubular epithelial cells and contribute to renal ischemia-reperfusion injury. J Immunol 2008;181:7489-7498.
21 Liu M, Chien CC, Burne-Taney M, Molls RR, Racusen LC, Colvin RB, Rabb H: A pathophysiologic role for $\mathrm{T}$ lymphocytes in murine acute cisplatin nephrotoxicity. J Am Soc Nephrol 2006;17:765-774.

22 Krishnan N, Perazella MA: Drug-induced acute interstitial nephritis: pathology, pathogenesis, and treatment. Iran J Kidney Dis 2015;9:3-13.

23 Wearne N, Swanepoel CR, Boulle A, Duffield MS, Rayner BL: The spectrum of renal histologies seen in HIV with outcomes, prognostic indicators and clinical correlations. Nephrol Dial Transplant 2012;27:4109-4118.

24 Yung S, Chan TM: Mechanisms of kidney injury in lupus nephritis - the role of anti-dsDNA antibodies. Front Immunol 2015;6:475.

25 Foster MH: T cells and B cells in lupus nephritis. Semin Nephrol 2007;27:47-58.

26 Issa F, Schiopu A, Wood KJ: Role of T cells in graft rejection and transplantation tolerance. Expert Rev Clin Immunol 2010;6:155-169.

27 Cho E, Lee JH, Lim HJ, Oh SW, Jo SK, Cho WY, et al: Soluble CD25 is increased in patients with sepsis-induced acute kidney injury. Nephrology (Carlton) 2014;19:318-324.

28 Yang SH, Lee JP, Jang HR, Cha RH, Han SS, Jeon US, et al: Sulfatide-reactive natural killer $T$ cells abrogate ischemia-reperfusion injury. J Am Soc Nephrol 2011;22:1305-1314. 